\title{
GANDHIAN IDEAS OF GRASSROOT DEVELOPMENT AND INDIAN DEVELOPMENT POLICY IN 21ST CENTURY (SPECIAL REFERENCE OF PANCHAYAT RAJ INSTITUTIONS)
}

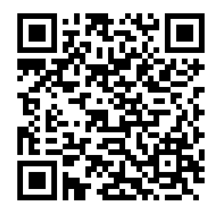

Sudip Mandal ${ }^{*}$ 凹 iD

${ }^{* 1}$ M.Ed. trainee of Ramakrishna Mission Sikshanamandira, Belur Math, Howrah, (W.B.), India

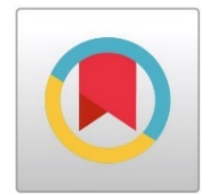

DOI: https://doi.org/10.29121/granthaalayah.v8.i11.2020.1990

Article Type: Research Article

Article Citation: Sudip Mandal. (2020). GANDHIAN IDEAS OF GRASSROOT DEVELOPMENT AND INDIAN DEVELOPMENT POLICY IN 21ST CENTURY (SPECIAL REFERENCE OF PANCHAYAT RAJ INSTITUTIONS). International Journal of Research GRANTHAALAYAH, 8(11), 100-105. https://doi.org/10.29121/granthaa layah.v8.i11.2020.1990

Received Date: 12 October 2020

Accepted Date: 30 November 2020

Keywords:

Village Panchayat

Democratic Decentralization

Panchayat Raj

Gram Sabha

\section{ABSTRACT}

In the recent times, 'Good Governance' is associated with efficient and effective of administration in a democratic framework and responsiveness of the state and its institutions. The main key elements of 'Good Governance' refer that respect for human rights, equity, rule of law, transparency in public procedure, strong democracy and capacity in public administration. The ideal democracy depends upon the equality of all the purely public opinions. In the same way Gandhian ideas of Panchayat Raj system is a broad concept in independent India and it is a transparency of government in public administration as a part of good governance. It was a concept of diffused grass-roots democracy and process of democratic decentralization. It's a large number of rural people who are directly involved in the field of democratic participation. From ancient times the village has always been regarded as the primary unit in the governance of India. Important govt. policies are implemented through panchayats. The Gram Sabha plays an important role in the whole Panchayat Raj institution in India's democratic system. This is a purely qualitative study. So, Present study is going to focus on the Gandhian point of view Panchayat Raj. This is necessary to development in India 21st century and this conception go ahead powerful in the Nation.

\section{INTRODUCTION}

Panchayat Raj was the most valuable component of Mahatma Gandhi's vision of future India in which economic and political power would be decentralized on the grassroots level and each village would be self-sufficient and selfreliant economically. According to him a rural society based on the self-sufficient village unit would be in a better position to maintain its freedom than an urban society. Every village would be a republic as well as highly decentralized, autonomous and non-violent character of the village society. His firm conviction was that the very idyllic nature of the Indian village life. Gandhiji's Village Panchayat Raj was concernedd with the creation of a peaceful and harmonious way of living which would be recovered to the rural life through self-reliance, selfsufficiency, co-operation and peaceful existence among all sections of village people. Gandhiji sought to revive the first Panchayati Raj tradition in India. After independence, the village panchayat was introduced in the Indian constitution keeping in mind the thoughts of Gandhiji. Constitution makers had set the national goal of creating a welfare state so that the aspirations of the people would be increased very quickly and it was not enough to exercise the power of the central and state governments in order to expand deeply into the grassroot levels of democracy.

(C) 2020 The Author(s). This is an open access article distributed under the terms of the Creative Commons Attribution License, which permits unrestricted use, distribution, and reproduction in any medium, provided the original author and source are credited. 
The main purpose of decentralization is to engage the common people in the development process and to bring transparency of government. 'Good governance' is a special key part of transparency in public administration. The responsiveness of the state and its institutions to the needs and aspirations of the people, and inclusive citizenship are imperative to good governance. Accordingly, for the rural development of the 73rd Constitution Amendment Act of 1992 gave the Panchayat constitutional status and this law introduced the three-tire-panchayat system in all India. The Constitution Amendment Act calls for the formation of a Gram Sabha in each village panchayat area. This Gram Sabha is an organ of direct democracy. Gram Panchayat can encourage the rural people to participate in the maximum amount for the various socio-economic development programs of the village.

\section{OBJECTIVES OF THIS STUDY}

The objectives of this study are as follows

1) To find out the Gandhian view of Panchayat Raj.

2) To find out the useful development of India in 21st century, concept is making in the powerful Nation.

\section{METHODOLOGY}

The qualitative study has been taken along with descriptive analysis to explore the Gandhian concept of Grassroots Development and India's Development Policy on the special reference of Panchayat Raj Institutions.

\section{SIGNIFICANCE OF DEMOCRATIC DECENTRALIZATION}

Gandhiji favored decentralization of governance rather than establishing central authority for self-government. He was a high believer in the concept of democratic decentralization which was introduced hypothetically for the formulation of Non-violence (This idea was based on the writing of Leo Tolstoy and the later Kropotkin.) as well as truth and individual freedom. He asserted that democratic decentralization should be possible mainly non-industrial society with the self-sufficient village as the basic unit of organization. He wanted to establish a system of governance at the village level. There was no state or government to control the rights of the individual. He called it village swaraj or panchayat raj. Gandhiji wanted to see each village a little republic, self-sufficient and rural people would enjoy maximum independence in decision making in rural socio-economic development. He also wanted to distribute political power among the villages in India and he described the word Swaraj what he called a true democracy. This democracy is built on the basis of freedom. Individual freedom, in Gandhiji's view, could be maintained only the political self-government or self-rule of the people and autonomous, self-sufficient village communities that offer opportunities to the villages people for full participation in the democratic process. According to Gandhiji decentralization of political power is the basic requirement for the success of true democracy.

\section{VILLAGE PANCHAYAT}

Gandhiji dreamed of extending democracy to the grassroot levels and this dream can be realized only through the Gram Panchayat.The village system is managed by a number of functionaries and it works as an autonomous sociopolitical unit. Panchayati Raj institution is an important tool for establishing democracy at the grassroots level in economic and political affairs. After traveling across the all over country, Mahatma Gandhi's conviction was that Indian villages were very idyllic nature of living and high thinking, so if the villages could be managed by the Gram Panchayat, then India would be benefited. There are every village republics, having full powers which are self-reliant and self-sufficient which all that people want. The minimum standard of living can be provided to all people through the Panchayat Raj system where a person has the maximum freedom and the opportunity to develop his personality. So gradually these republics continue to degenerate the state and the foundation of democracy becomes stronger. According to Gandhiji without adequate power, the centralized system could not be perpetuated. Gandhiji's ideal political system was not a pyramid-shaped federal structure. This ideal political structure was like a sea wave (Oceanic Circel), where each wave had its own distinctiveness and was not dependent on others. The Panchayat will decide all matters of the village and the every Panchayat will be formed with five persons, annually elected by the adult villagers, male and female, possessing minimum prescribed qualifications. They are committed to the 
development of the village. Gandhiji's main goal was to have a person at the center of local governance. People will take a personal interest and expect a large number of people to attend a meeting of common interest issues such as village industries, agricultural production, obligations and planning. The small communities or villages, in which voluntary co-operation, is the condition of dignified and peaceful existence.

\section{VILLAGE -UNIT OF A DEVOLUTION SYSTEM}

Gandhi made it very clear that focusing of either economic or political power would violate all the necessary principles of participatory democracy. He was against the center being too strong, Panchayat Raj institution can also be considered as the parallel politics of decentralization and as units of economic autonomy. The last unit of the decentralization process is the village. In fact that the formation of village panchayat, Gandhian vision of panchyat raj system is essential to maintain and shared political power among the people. They will be able to self- managed and self- regulated their own local organization. They are participate to decision-making process and implementation are done by the local people, so that they will be the authoritative of this institution. It is run through the collective will of all the individuals. Village is the primary unit of participatory democracy. The philosophy of political decentralization is a creation of panchayat raj with parallel politics in which people's empowerment is to counter the centralizing and alienating forces of the modem state. According to Gandhiji, development of Panchayat system would be possible through proper use of local resources. In the field of local industries and agriculture, development would come up through village meetings of Gram sabha and the panchayats would have to be organized that way. Gandhiji's dream village is a small republic, self-sufficient, enjoying maximum freedom and the village panchayat can be the director of rural society and economy. At the same time, all decisions regarding rural matters are entitled to be made. Gandhi's undertaking a plan of government under the Gandhian Constitution starting from the primary unit, the Village Panchayat to the balance of the All India Panchayat Raj, where power has been entrusted to all levels of government. Therefore, that every village will not only be self-sustained, it will be capable of managing its affairs even to the extent of defending itself against the whole world.

\section{PANCHAYAT RAJ SYSTEM}

The Gandhian concept of Gram Swaraj and Panchayat Raj system is an important weapon which can become vehicles for the social and political change by including all the stakeholders in the process of decision-making and policy formulation. Emphasis is placed on the empowerment and political awareness of the rural people. Friendship mentality among the all local people will play a positive role in building brotherhood, people will be aware of social duty-responsibility and cooperation. It is clear that Gandhiji's Panchayati Raj system is represent to real democracy.

\section{INDIAN DEVELOPMENT POLICY REGARDING PANCHAYAT RAJ INSTITUTIONS}

Mahatma Gandhij's clear statement about Panchayat Raj, it is a presenting a picture of highly decentralized form of village government in which is perfect democracy based upon individual freedom and law of non-violence, and each village is responsible for its own affairs, as the foundation of India's political system. In Gandhiji's view, such word is Gram Swaraj (Village self-government). By the way, after independence the constitution of India comes into force on 26th january 1950 as well as the Indian Constitution is being called directive principles of state policy mention village panchayats as 'units of self-government'(Art. 40). The Government of India appointed Balwant Rai Mehta Committee in jan,1957 to experiment the programme of the Community Development Programme (1952) and the National Extension Service (1953) and to suggest measures for their better working. The main goal of the Community Development Programme (1952) is to achieve the socio-economic development of the rural population. These recommendations of the committee were accepted by National Development Council in January 1958. The Committee recommended the organization of the plan of 'democratic decentralization' which is finally came to known as Panchayat Raj. Establishment of a three-tier Panchayati Raj system---gram panchayat at the village level. Rajasthan was the first state in all over India to establish Panchayati Raj. Formally in this project was introduced by the the Prime Minister Jawaharlal Nehru on Oct 2, in Nagaur district at Rajasthan. Thereafter, several state governments adopted the Panchayati Raj system during the 1950 to 1960. Finally decline of first generation 
Panchayati Raj Institutions. Later on the law was passed through the 73rd Constitution Amendment in 1992 under the leadership of Prime Minister Narasimha Rao. Panchayat is described as an 'Institutions of Local Self Government' in Article 243 of the Indian Constitution. The 73rd Amendment Act 1992 has provided Constitutional status to the Panchayati Raj Institutions and is a step in the direction of speeding up the process of decentralization and giving power as well as responsibility and stability to local institutions. For the preparation of establish economic development and social justice, Local government independently will create all plans and implement all affairs. Seventy-Third Amendment Act,1992 has added a new Part-IX entitled as ' the panchayats' and a new Eleventh Schedule (Article 243G) containing 29th functional items of the panchayats. This subject of 'Local Government' is mentioned in the State List (66 Subjects) under the Seventh Schedule (Article 246) of the Constitution.

\section{GRAM SABHA - SOCIAL AUDIT}

In the new system the Gram Sabha is a very important role play of Panchayati Raj Institution in 21st century. Gram Sabha is a general assembly of the all villagers. Though, The Ministry of Panchayat Raj has issued specific guidelines for the formation of effective platform Gram Sabha through in the planned economic and social development of the villages in a transparent way. The guidelines are a part of the proceedings to observe the year 2009-10 as year of Gram Sabha and relate to the social audit for the effective implementation of Mahatma Gandhi National Rural Employment Guarantee (MGNREG) Act 2005. It also Pradhan Mantri Gram Sadak Ayojana (PMGSY) is a $100 \%$ centrally sponsored scheme and all the road works will be subjected to Social Audit by way of discussion in the Gram Sabha. According to the guidelines, the Gram Sabha is a Key to the self-governance and It is through the gram sabha that the elected representative is made accountable to the electorate. At the same time, Gram Sabha has to meet periodically with maximum participation of the people. The poor men, women and marginalized citizens equally participate in the village meetings on the Gram Sabha and the decision is made on the basis of local priorities through discussion and debate of proposals based on local problems. Gram Sabha shall approve of plans, programmes and projects for social and economic development before they are taken up for implementation by the Panchayat at the village level and responsible for the identification of beneficiaries under the property alleviation and other programmes. For that, active functioning of the Gram Sabha is the primary unit of participatory democracy with transparency, accountability and achievement as well as it is the voice of democracy. Only if Gram Sabhas are vigilant and sensitive to their own problems, the Panchayati Raj institutions become successful. So, the Gram Panchayat must consult with the Gram Sabha to determine the policy at the grass root level as well as it will also be possible for ordinary poor villagers to participate in setting the policy of Panchayats. Therefore, the importance of the Gram Sabha is increasing steadily such as very recently Ministry of Panchayati Raj have been launched Sankalp se Siddhi Abhiyan $\square$ New India Movement (2017?22) through statistics 2,56,590 Gram Sabhas for Sankalp Se Siddhi Programme, 2,95,41,901 people participated and awarded for the very recently outstanding performance through effective Gram Sabhas of Gram Panchayats have been selected with Nanaji Deshmukh Rashtriya Gaurav Gram Sabha Puraskar (NDRGGSP).

In the indian Constitution mentioned here the Article 243G under the Legislature of the state may, by law endow the Panchayats with such powers and authority as may be necessary to enable them to function as institutions of self-government and including the Eleven Schedule. Such laws may also endow powers and responsibilities upon Panchayats for the preparation and implementation of plans for economic development and social justice including in relation to the 29 matters listed in the Eleventh Schedule. This lead to the enactment of Gram Panchayat Acts by various States; these are no more than half-hearted attempts for the creation of rural local government institutions.

\section{CONCLUSION}

The studies of several eminent scholars are working with Panchayatiraj in different states and the Status Report of the Ministry of Panchayat Raj (1996) lead us to the inference that the unfinished work of Gandhian Ideal of Village Swaraj was implemented on 2 October 1959, as recommended by the Balwant Rai Mehta committee. Panchayat Raj Institution was formed through the 73rd Constitutional Amendment Act of 1992 under the leadership of Prime Minister Narasimha Rao. It came into force on 24th April,1993. Although in rural areas the system of panchayats is still controversial due to lack of proper education, because of the narrow-minded sectoral interests, etc., in almost 
all states, panchayats have been given various levels of autonomy. Apparently that the present scenario of the social, political and economics empowerment to village development of the Panchayati Raj system in the true sense is successful in the twenty-first century (In the sense from 1993 to 2020). At the same time, there is no doubt that Gandhiji's idea of decentralization of self-reliant development is a very relevant subject today and it is reflected in the various welfare projects of the states and central government to make in powerful Nation through the gram panchayats more motivated, self-reliant, strong and to ensure the momentum of development. For example the central government has announced an additional allocation of Rs 40,000 crore for the Mahatma Gandhi National Rural Employment Guarantee (MGNREG) Project in the current financial year. The Rural Development Minister said that Rs 1 lakh 20 thousand crore was allocated in the budget for the financial year 2020-2021 but it is in excess of that. The adoption of this policy by the Government of India is certainly part of building a powerful Nation and State. Gandhiji's Hind Swaraj explains the $\square$ all Indian economic (and political) model $\square$. Very recently announcement our Prime Minister Narendra Modi $\square$ s idea of $\square$ Atmanirbhar Bharat $\square$ or self-reliant India is same as Gandhiji $\square$ s behalf of modernisation but no Western dependence. At the same time he emphasized the importance of promoting $\square$ local $\square$ products. Mainly science and technological development in the rural sector and socio-economic to democratic empowerment of the village people. In this way, by boosting the domestic economy, a self-reliant India and this policy is part of a powerful nation state will be formed. We are very optimistic but time will tell. Above all, the villagers need their common interest and continuous support for rural social and economic development. Therefore, the joint effort of all is needed to empower the rural people through the Gram Swaraj of Gandhiji's dream and participatory democracy construct to India's national development.

\section{SOURCES OF FUNDING}

This research received no specific grant from any funding agency in the public, commercial, or not-for-profit sectors.

\section{CONFLICT OF INTEREST}

The author have declared that no competing interests exist.

\section{ACKNOWLEDGMENT}

None.

\section{REFERENCES}

[1] Bandyopadhyaya J., Social and Political Thought of Gandhi, Calcutta, Prasanta Aditya, Manuscript India, 2000, p. 63,101

[2] Bhattacharya M. \& Ghosh B., Public Administration and Planning, Kolkata, The World Press Private Limited, February 2007, p. 304-314

[3] Basu A., Paschimbange Panchayat Byabastha, Kolkata, West Bengal State Book Board, Jan 2018/B

[4] Bhattacharya M., New Horizons of Public Administration, New Delhi, Jawahar Publishers \& Distributors, 2013, p. 108

[5] Basu R., Public Administration, Kolkata, West Bengal State Book Board, Aug 2013/C, p. 132-144

[6] Chakraborty B., Local Government: Concept, Organisational Base and Different Approaches, Kolkata, Progressive Publishers, Jan 2008, p. 113

[7] Chakraborty B., Paschimbanger Panchayat Byabasthar Ruprekha, Kolkata, Progressive Publishers, April 2008

[8] Chapter 6, Gandhian Concept of Rural Development, Retrieved from https://www.google.com/url?sa=t\&source=web\&rct=j\&url=https://shodhganga.inflibnet.ac.in/bitstream/1 0603/307/13/13_chapter6\&ved=2ahUKEwi2w9m-

fnnAhUDIbcAHc00AvIQFjAGegQIBBAB\&usg=AOvVaw0Y7toSDd1ZR_yiT6tzWaFq 
[9] Dhameja A. \& Mishra S., Public Administration (Approaches and Applications), Delhi \& Chennai, Pearson, 2016 p. 230,260

[10] Devare M. S. (2015) Gandhian thought of Rural Development Retrieved from https://papers.ssrn.com/sol3/Delivery.cfm/SSRN_ID2664530_code2450204.pdf?abstractid=2664530\&miri $\mathrm{d}=1$

[11] Gandhi, M.K., Harijan, 28 July 1946, p. 236

[12] Government of India, The Constitution of India, 1st Feb 2011, p. 20

[13] Government of India, The Constitution of India, 1st Feb 2011, p. 106

[14] Gandhi, M.K., Harijan, 26 July 1942, p. 238

[15] Ghosh S., Janaprashasan Tatwa O Prayog, Kolkata, Progressive Publishers, Feb 2019, p. 449-518

[16] Garg B. S.and Raut A.V. Adarsh Gram: A Gandhian Dream of Gram Swaraj, Indian J Community Med. 2015 JanMar; 40(1): 104. retrieved from https://www.ncbi.nlm.nih.gov/pmc/articles/PMC4317974/

[17] Government of India Ministry of Panchayati Raj, Important Achievements of Ministry of Panchayati Raj during the Four-Year period 2014-15 to 2017-18: Retrieved from https://www.google.com/url?sa=t\&source=web\&rct=j\&url=http://pibarchive.nic.in/4YearsOfNDA/Compre hensive-Materials/ Panchayati\% 2520Raj. Pdf $\quad \& \quad$ ved=2ahU $\quad$ KEwjC4 dPeu_vnAhXPbX0KHcJRBTIQFjAJegQICRAB\&usg=AOvVaw2-8APJZm uUBJ0dcGh yBFYU

[18] Kashyap C. S., Our Political System, New Delhi, National Book Trust, India, p. 227-256

[19] Madhumathi M. (2011) The Gandhian Approach to Rural Development retrieved from https://www.google.com/url?sa=t\&source=web\&rct=j\&url=http://www.ijcrt.org/papers/IJCRT1133061.p df\&ved=2ahUKEwjQqcSqgPrnAhWLe30KHaKSC8o4ChAWMAd6BAgDEAE\&usg=AOvVaw0k5XNcYpWHV5XRTgdS_tA

[20] Mondal P., The Gandhian Approach to Rural Development (1713 Words) Retrieved from http://www.yourarticlelibrary.com/mahatma-gandhi/the-gandhian-approach-to-rural-development-1713words/4797

[21] https://www.indiabudget.gov.in/

[22] https://m.economictimes.com/news/economy/policy/budget-2020-mgnrega-funds-down-by-13-marginaldip-in-other-rural-deelopment-

schemes/articleshow/7347723.cms\#: :text=Union\%20Finance\%20Minister\%20Nirmala\%20Sitharaman, was\%20at\%20Rs\%2071\%2C001.81\%20crore.

[23] https://indianexpress.com/article/explained/narendra-modi-coronavirus-economic-package-india-selfreliance-6406939/

[24] https://indianexpress.com/article/business/centre-to-pump-rs-40000-crore-more-into-mgnrega-for-fy216414887/

[25] https://www.gandhiashramsevagram.org/on-economy/village-development-and-economy-of-country.php

[26] https://ruraldiksha.nic.in/RuralDashboard/MGNREGA NEW.aspx

[27] https://rural.nic.in/ 